\title{
Primordium initiation drives tree growth
}

\author{
Ronald M. Lanner ${ }^{1}$
}

Received: 22 August 2016 / Accepted: 14 December 2016/Published online: 7 February 2017

(C) INRA and Springer-Verlag France 2017

\begin{abstract}
- Key message Tree growth is driven by leaf primordium initiation at shoot apices through a series of growth and developmental events largely mediated hormonally and often determinate in nature. This repeating pattern keeps trees alive and reproductive and conserves the phenotype.
\end{abstract}

Keywords Morphogenesis · Shoot elongation ·

Photosynthesis $\cdot$ Xylogenesis $\cdot$ Phenotype conservation

\section{Introduction}

I have become increasingly convinced that this cycle is an entity so well integrated that it seems hardly possible to investigate or survey any of its parts successfully if they are separated from the whole (Sarvas 1974, p. 3).

Each year, a tree makes itself anew by adding modules of primary and secondary growth to the surface of the previous year's crown, stem, and roots. This deposition of new growth keeps the tree alive, as no tree can persist without renewing its tissues. It also allows the tree to achieve a size and physiological stage of maturity that supports sexual reproduction. Moreover, it replicates the distinctive species phenotype,

\section{Handling Editor: Erwin Dreyer}

Ronald M. Lanner

pinetree30@comcast.net

1 Institute of Forest Genetics, Pacific Southwest Research Station, USDA Forest Service, Placerville, CA, USA which results from the interplay of genome, and environment broadly construed.

How then are primary and secondary growth initiated and controlled to yield the uniform product of each year's growth cycle? What provides the stimulus that drives the growth of apical and lateral meristems when internal and external conditions are conducive to biological activity?

I propose here that the initiation of leaf primordia on shoot apical meristems that sets in motion the annual suite of tree growth activities. This may occur immediately or after a period of dormancy. Once begun, those growth activities proceed to completion, unless prevented by disturbance or resource depletion.

The determinate nature of this synthesis does not exclude familiar sources of variability. Even determinate processes that are predictable in their outcome are influenced by environmental variation, historical events in a tree's long developmental time frame, and the unique genetic legacies of each taxon. Much of the supporting evidence cited below originated from studies in Pinus because pines are the most studied of trees. Precise applicability to other taxa remains to be determined. The concept of leaf primordium initiation as a driving force for plant growth has been raised with regard to wheat (Triticum aestivum L., Hay and Kemp 1990) but appears to be a novel explanation for a complex woody plant.

\section{Some supporting findings}

\subsection{Formation of stem units following primordium initiation}

Stem units are anatomically associated with leaves and provide the organic connection between leaves and the stems bearing them. 
A tree's first shoot apical meristem is that of its embryo, and its first leaf primordia become the cotyledons (Foster and Gifford 1974). Here, we focus on the shoot apical meristems that form subsequently and that comprise the expanding, then declining, population of apical meristems active during a tree's lifetime.

Primordia are initiated by local cell division and enlargement on the shoot apical meristem (Wardlaw 1968). New primordia form successively above the last initiated, in the phyllotaxy characteristic of the taxon. Most will become embryonic leaves or scales which will overwinter, in many species of temperate regions, within a bud. They will mature in the next growing season as the bud elongates into a shoot. The shoot then lignifies, precluding its further elongation.

The portion of shoot associated with a leaf or scale is a stem unit defined by Doak (1935) in pines as "an internode, together with the node and nodal appendages at its distal extremity"; thus a portion of shoot, the scale at its upper end, and the needle fascicle in the axil of that scale. An internode per se comprises that part of a stem between points of attachment of successive leaves (nodes), but it does not include the leaf itself. The term "internode" is ambiguous because it has traditionally been used in forestry to denote that part of a stem between successive branch whorls, and alternative nomenclatures have been proposed to remedy the resulting confusion (Critchfield 1985, Powell 2009).

Stem units can be measured by counting those on a shoot segment of known length to obtain the mean stem unit length (MSUL). Young leaves produce plant growth regulators (PGRs) that induce vascular tissues in the immediately subjacent stem (Aloni 2013). These form leaf-bearing stem units that can be regarded as the major building blocks of the young woody shoot.

In bud-forming temperate-zone trees, stem units are typically initiated within buds in the year " $n$ ", and the bud elongates into a shoot in " $n+1$ " (Lanner 1968). The number of stem units formed in a bud depends on how rapidly each forms (the plastochron) and for how long the process continues (Cannell and Willett 1975).

\subsection{Properties of stem units}

When a pine bud elongates in the spring, its stem units start to grow almost simultaneously. Growth cessation however proceeds from the base of the growing shoot upwards. The most proximal and distal stem units grow to about $2 \times$ the length they held in the dormant bud. The leaf-bearing stem units, which comprise most of the shoot's length, elongate to as much as $10 \times$ their length in the dormant bud (Lanner 1968). Thus, a stem unit's contribution to the overall growth of its shoot depends on its location. The sequence of stem unit elongations and their final lengths may be partly responsible for the ubiquitous sigmoid curve of shoot growth.
Within a class of similar shoots (e.g., same species, provenance, age class, crown position, branch order), leaf-bearing stem units attain a rather uniform average length under normal conditions. For example, MSUL was uniform throughout the crowns of sapling red pine (Pinus resinosa Ait.) and eastern white pine (Pinus strobus L.), though larger, older red pines showed a gradient, with shorter stem units in the lower branches (Lanner 1968). Buckbee (1977), however, found an inverse relationship between MSUL of lateral branches and height in the crowns of subalpine firs (Abies lasiocarpa [Hook.] Nutt). The leaders of suppressed eastern white pines had shorter and fewer stem units than dominants (Lanner 1968), as had those of lodgepole pines (P. contorta Dougl. ex Loud.) in stagnated thickets in British Columbia (Worrall et al.1985).

Stem unit length can be affected by dominance relationships within a tree. Thus, Little (1970) found that when some elongating shoots were removed from eastern white pine whorls, the remaining shoots exhibited increased ("compensatory") growth. As stem unit number in eastern white pine is predetermined in year $\mathrm{n}$, the added growth presumably resulted from increased stem unit length. In leaders of slash pine saplings (Pinus elliottii Engelm.), MSUL of first summer shoots exceeded those of spring shoots and of second summer shoots (Lanner 1978).

In Great Basin bristlecone pine (Pinus longaeva D. K. Bailey), neither shoot length, stem unit number, nor stem unit length showed a consistent trend when regressed on tree age (Connor and Lanner 1989). Therefore, aging in these trees cannot be defined in terms of diminishing annual shoot growth.

Stem unit characteristics may affect tree form. Subalpine fir leaders bore stem units "by far the longest in the tree," which Buckbee (1977) suggested accounts in part for the distinctive spirelike form of the species. On the other hand, Lanner (1989) attributed the umbrella crown of Italian stone pine (P. pinea L.) to consistently longer stem units in the lateral shoots of its whorls than in the leaders of those whorls, despite the leaders having more of them.

The thinner crown of eastern white pine, compared to the denser red pine, may be due to white pine's much longer stem units (e.g., 2.88-3.68 mm vs.1.07-1.08 mm) in 12-year-old trees (Lanner 1968). Great Basin bristlecone pine and its close relatives are easily identified by the "tasseled" appearance of its branches due to its exceptionally short needles and closespaced fascicled stem units.

Provenance has a role in stem unit length and number. In a study of Scots pine (Pinus sylvestris L.) from Germany, Sweden, Finland, and a Belgian plantation, MSUL in Minnesota, Michigan, and Missouri plantings was 1.67, $1.68,1.59$, and $1.64 \mathrm{~mm}$, respectively (Lanner 1968). While these differences were trivial, the tallest provenance exceeded the shortest in height growth by about $225 \%$, illustrating the 
usually decisive effect of number of stem units (NSU) in determining shoot length (Lanner 1976). NSU correlated with shoot length in provenances of lodgepole pine and western white pine (Pinus monticola Dougl. ex D. Don (Chuine et al. 2001, 2006), eastern white pine (Major et al. 2009), and Scots and lodgepole pines (Norgren et al.1996). However, Kremer and Larson (1983) reported that in jack pine (Pinus banksiana Lamb.), NSU was the stronger predictor of height growth between provenances and MSUL in families within provenances. Half-sib loblolly pine families had longer annual leaders due to either greater MSUL or greater NSU (Bridgwater 1990).

As Cannell et al. (1976) have expressed it, "some genotypes may be predisposed to extend individual stem units more than others, and this may be inherited separately from factors affecting stem unit numbers."

The usually strong correlation of NSU and future shoot length has apparently settled the question of whether shoot length is determined mainly by conditions of the prior year or the elongation year, for many decades controversial among European and American foresters. Temperature and soil moisture commonly make their impacts through the process of primordium initiation. Thus, final shoot length of Scots pine in northern Finland was determined by the summer temperature of $n$, not $n+1$ (Salminen and Jalkanen 2004). Dobbertin et al. (2010) showed the importance of previous-year conditions on shoots elongating from preformed buds: droughtstressed Scots pine doubled their shoot growth the year after being irrigated, while cambial growth increased during the year of irrigation. Feichtinger et al. (2015) found Scots pine on a dry site reacted immediately to a severe growing season drought in 2011 with decreased needle and xylem growth, but shoot growth and fascicle numbers decreased in 2012, responding to lesser stem unit production. Garrett and Zahner (1973) have reported similar drought responses in red pine.

\subsection{Determinate growth}

Like an animal organ (Goss 1966), a stem unit tends to attain a specific size. It is therefore a determinate structure, defined by Sinnott (1960), as having a growth cycle of its own, ceasing growth at maturity, and lacking a meristematic region capable of later growth. This is true also of the cells that form stem units, as shown by measurements of pith cells in normal and aberrant (e.g., drought affected, dwarfed, etc.) stem units of various pine species (Lanner 1968). Pith is the mature condition of rib meristem parenchyma originating below the shoot apical meristem (MacDonald and Little 2006). In almost all cases, pith cell length in shortened stem units did not differ significantly from that of normal ones, pointing to reduced cell division as the cause.
Because it is determinate, a shoot's final size is not the product of growth rate and time. Rather, its growth period depends on the rate at which it attains its predetermined final size. Haber et al. (1964) recognized this distinction between mathematical and biological determination in studies of wheat epiblasts. It can also be seen in the data of many tree growth studies (see Lanner 1968). Salminen and Jalkanen (2007) state that: "Because growth rate is temperature driven, temperature also affects the duration of predetermined height growth of pines. Once the growth units of pines are fully elongated, height growth ceases." Growth rate refers here to the rapidity of shoot elongation during the growing season ("intra-seasonal growth"). Such growth rates are sensitive even to hourly fluctuations of temperature (Lanner 1964), but they may be irrelevant to final length. Salminen and Jalkanen's view is consistent with that expressed in this synthesis, but not with that of Schiestl-Aalto et al. (2013) which attributes growth increment to the dynamics of growth during the elongation period or to that of Huang et al. (2014) that trees "must follow a biological clock to grow by perceiving the changes in day length during the growing season" in order to complete growth within a limited growing season. Reconciling these views would seem essential to fully understand tree growth.

Early shoot growth cessation in a warm summer may be followed by a longer primordium initiation period, producing more stem units for the next year's shoot (Lanner 1976). If so, a warming climate may allow this ability to be expressed on currently cooler sites when moisture is non-limiting.

\subsection{Leaf number and leaf biomass}

Developing leaves appear to be necessary for stem units to fully elongate. When developing fascicles were removed from elongating shoots of ponderosa pine (P. ponderosa Dougl. ex Laws.), the associated stem units elongated far less than those with intact fascicles. Removal of shoot apical meristems, however, had no effect on shoot elongation (Lanner and Connor 1988). Wang et al. (1997) found similar results in Scots pine. These findings suggest that PGRs are produced in the developing fascicles, consistent with Tepper's (1969) observation that in the reactivation of dormant red pine buds, mitoses first appeared in the immature fascicles.

The amount of leaf tissue, an outcome of primordium initiation, sets limits on the tree's photosynthetic potential and its ability to make and store carbohydrate. It therefore limits the tree's metabolic potential in general, from its ability to construct tree components, synthesize secondary substances, conserve surpluses available for reproductive organ formation, etc. Leaves facilitate tree hydration, as their stomates provide the atmospheric interface of cohesive sap columns delivering soil water to the tree tissues. Not to be overlooked is the potential of a larger crown of foliage to produce a greater volume of PGRs, notably auxin and gibberellins, whose 
synergistic action leads to increased production of xylem (Aloni 2013).

The leaf biomass a tree can produce is limited by the rate and duration of leaf initiation in apical meristems. The outer limit of a single meristem's activity over a known period may be approached by a Hawaiian rainforest-grown "foxtail" of Monterey pine (Pinus radiata D. Don). The terminal bud of this $5.6 \mathrm{~m}$ unbranched leader produced about 3200 needle fascicles in 5 years of continuous growth, with many more concealed by bud scales (Lanner 1966).

\subsection{Some roles of plant growth regulators}

The growth regulators (phytohormones) most influential in tree growth are the auxin indole-3-acetic acid (IAA), and several forms of gibberellic acid (GAs). IAA is the most common naturally occurring auxin and the major regulator of vascular differentiation. However, cytokinins (CKs) produced largely in the root cap, abscisic acid (ABA), and strigolactones (SLs) also have roles in the regulation of cambial activity (Aloni 2013). Adding to the complexity of the hormonal brew in a tree's tissues is the "cross talk" or interaction among them.

While Aloni (2013) terms IAA the "young leaf" signal, it has also been shown to form in significant quantities in 1-yearold stem tissues of Scots pine (Sundberg and Uggla 1998). IAA moves down the tree from new crown growth to root tips, mainly via the vascular cambium, inducing xylem and phloem formation along the way (Aloni 2013), though the regularity of this scenario has recently been challenged (Li 2016). Uggla et al. (1996) have shown that, in Scots pine, IAA controls cambial growth through positional signaling, resulting in a chain of cause-and-effect relationships. Thus, the quantity of IAA moving down the tree in the cambium determines the radial extent of an auxin gradient, which in turn controls cambial growth rate by affecting the radial width of the cambial zone. This pool of IAA is mainly produced in the leaves of growing stem units in the upper and outer crown and can be viewed as a long distance signal that correlates growth of the apical organs and the vascular cambium (Sundberg and Uggla 1998). It would appear logically consistent with this interpretation that the number of developing stem units producing IAA at this time would be a crucial component of the cambial growth system. This would be a direct consequence of the magnitude of primordium initiation at shoot apices. New findings regarding mechanisms of auxin transport in the stem may force some re-evaluation of these concepts (Bennett et al. 2016).

Wang et al. (1997) concluded that IAA in elongating shoots of Scots pine was sourced mainly in the shoot apex and the developing needles, and that with GA it was necessary for shoot growth. GA also originated mainly in needle fascicles. Little and MacDonald (2003) found that when GA was applied to Scots pine and white spruce (Picea glauca [Moench]
Voss) seedlings, longer stem units formed on the axis, and NSU was increased in developing terminal buds. They concluded that activity of both the subapical and apical meristems was stimulated by GA. The role of IAA in controlling stem unit number and length was inhibitory or ineffectual and considered unresolved. MacDonald and Little later (2006) determined that exogenous GA stimulated mitosis in the apical meristems of Scots pine seedlings, increasing the rate of primordium formation and its duration.

Regulation of the earlywood-latewood transition has also been suggested as an important hormonal role in wood formation. Larson (1964) concluded that early in the growing season, when shoots and needles were elongating in red pine, an abundance of IAA flowing downwards from the crown induced the formation of large thin-walled tracheids, but as crown growth and IAA concentration declined, the cambium produced the narrow, thick-walled tracheids typical of latewood. Rossi et al. (2009) point out that Larson's scenario requires that cambial activity follows bud break and that secondary cell wall thickening in the new xylem would proceed after shoot growth had ceased, yet that is not always the case. This is an active area of research in which more precise methods of studying the phenology of xylogenesis may lead to new insights (Lupi et al. 2014). A shortcoming of some phenological research is speculation about the early activity within winter buds entirely from external examination. By the time external indications of bud break are evident, needle primordia of numerous conifers are weeks or months old (Cannell et al. 1976) and may have generated PGRs well before the buds containing them were placed under observation. The matter is further complicated by a number of experiments, reviewed, and augmented by Begum et al. (2012), indicating that the cambium and its derivatives can respond directly to temperature change, reactivating as temperature increases, and transitioning to latewood on cooling. An unusual finding that supports Larson's interpretation is growth of the abovementioned Monterey pine foxtail in which 5 years of continuous shoot growth without a dormant period produced a stem $13 \mathrm{~cm}$ in diameter composed entirely of earlywood (Lanner 1966). Possible explanations of cambial activation occurring prior to bud break are the presence of phytohormones in mature stemwood or hormonal cross talk. This area needs clarification.

\subsection{Sink demand and photosynthesis}

For decades, there was much confusion about the relationship of growth rate and rate of photosynthesis in woody plants, largely centered on which was cause and which effect (Kramer and Kozlowski 1979), with evidence available that favored either interpretation. However, it is now 
widely accepted that photosynthesis is regulated by sink activity, generally the development of leafy shoots or fruit crops, through complex interactions that ultimately control the expression of photosynthesis genes (Paul and Foyer 2001). Some examples in which shoot growth comprises the sink follow. Photosynthetic rate in hybrid poplar (Populus maximowiczii Henry $\times$ P. nigra L.) increased when coppicing stimulated the emergence of new leaves (Tschaplinski and Blake 1995). There was a reduced demand for photosynthate following removal of growing loblolly pine (P. taeda L.) shoots, which resulted in reduced photosynthate formation in older needles (Myers et al., 1999). Also in loblolly pine, production of photosynthate increased during the elongation of spring shoots and then again when summer shoots elongated (Chung and Barnes 1980). Further evidence has emerged from studies of fruit trees in which the fruit comprises the sink: in Citrus (Ribeiro et al. 2012) and in Prunus (Quentin et al. 2014).

The fascicle-bearing stem units on a pine shoot may be of equal sink strength. Lanner and Connor (1988) placed lightproof aluminum bags over ponderosa pine buds coming out of dormancy, forcing the shoots to develop inside entirely on photosynthate imported from prior-year needles. The increase of dry weight per stem unit from bud stage to maturity was unaffected by the number of stem units, suggesting that the carbohydrate demands of a growing shoot are proportional to the number of stem units in the pre-formed bud. As active growth centers, sinks are the organs or regions that have the most need of photosynthate, both from storage and current production (Ryan and Asao (2014). The prioritized allocation of carbohydrates to these growth centers would seem to be a crucial precondition not only for robust development of the individual tree, but for faithful duplication of its phenotype as well.

\section{Discussion}

The basic proposal of this paper-that tree growth is driven by leaf primordium initiation at shoot apices-appears to be strongly supported. After that first step, a chain of growth events takes place in serial fashion, each of which depends on the earlier events having progressed or gone to completion. Thus, for example, leaf maturation leads to stem unit vascularization and elongation, which are followed by lateral meristem formation and activation, all mediated hormonally by the maturing foliage. Production of photosynthate is scaled to the needs of developing organs - sinks-and its transport to those sinks is at least partly through new vasculature. Quantitative aspects of these events are related to the magnitude of primordium formation. Atmospheric temperature is seen here as having its major effects in determining start times and rates of life processes, but as a transient influence. This contrasts with the view of Rossi et al. (2013) in which the cambium is regarded as a cell division machine triggered by temperature without consideration of shoot growth.

This synthesis is admittedly speculative and incomplete. Past research in tree biology has proceeded largely from a reductionist viewpoint, simplifying the part of the tree under study by isolating it from the whole functioning organism. This strategy has led to great advances in our understanding, but it has left unmet the need to integrate and synthesize, and it precludes an evolutionary perspective.

The findings discussed here raise a teleological question that may be useful as a thought experiment: Can a tree be viewed as a goal-seeking organism genetically programmed to develop into a sexually mature exemplar of a selected phenotype? It appears to accomplish such a goal by linking its developmental processes into a sequence of causes and effects managed by internal control systems largely unaffected by the normal range of environmental fluctuations. This determinate view is not one that is often expressed critically or otherwise. The primary event driving that development is the repetitive initiation of leaf primordia at innumerable shoot apices, a subject long neglected in studies of forest trees.

\section{References}

Aloni R (2013) The role of hormones in controlling vascular differentiation. In: Fromm J (ed) Cellular aspects of wood formation. Plant Cell Monogr. 20, Springer-Verlag, Berlin, pp 99-139. doi 10.1007/9783-642-36491-4_4

Begum S, Nakaba S, Yamagishi Y, Yamane K, Islam MA, Oribe Y, Ko J$\mathrm{H}$, Jin H-O, Funada R (2012) A rapid decrease in temperature induces latewood formation in artificially reactivated cambium of conifer stems. Ann Bot 110:875-885. doi:10.1093/aob/mcs149

Bennett T, Hines G, van Rongen M, Waldie T, Sawchuk MG, Scarpella E, Ljung K, Leyser O (2016) Connective auxin transport in the shoot facilitates communication between shoot apices. PLoS Biol. doi:10.1371/journal.pbio.1002446

Bridgwater FE (1990) Shoot elongation patterns of loblolly pine families selected for contrasting growth potential. For Sci 36:641-656

Buckbee MA (1977) The relationship of stem unit number and length to shoot length in Abies lasiocarpa (Hook.) Nutt. Thesis, Utah State University

Cannell MGR, Willett SC (1975) Rates and times at which needles are initiated in buds on differing provenances of Pinus contorta and Picea sitchensis in Scotland. Can J For Res 5:367-380

Cannell MGR, Thompson S, Lines R (1976) An analysis of inherent differences in shoot growth within some north temperate conifers. In: Cannell MGR, Last FT (eds) Tree physiology and yield improvement. Academic, London, pp 173-205

Chuine I, Aitken SN, Ying CC (2001) Temperature thresholds of shoot elongation in provenances of Pinus contorta. Can J For Res 31: 1444-1455 
Chuine I, Rehfeldt GE, Aitken SN (2006) Height growth determinants and adaptation to temperature in pines: a case study of Pinus contorta and Pinus monticola. Can J For Res 36:1059-1066

Chung HH, Barnes RL (1980) Photosynthate allocation in Pinus taeda. III. Photosynthate economy: its production, consumption and balance in shoots during the growing season. Can J For Res 10:348356

Connor KF, Lanner RM (1989) Age-related changes in shoot growth components of Great Basin bristlecone pine. Can J For Res 19: 933-935

Critchfield WB (1985) Internode or stem unit: a problem of terminology. For Sci 31:911-912

Doak CC (1935) Evolution of foliar types, dwarf shoots, and cone scales of Pinus with remarks concerning similar structures in related forms. Ill Biol Monogr 13(3):1-106

Dobbertin M, Eilmann B, Bleuler P, Giuggiola A, Pannatier EG, Landolt W, Schleppi P, Rigling A (2010) Effect of irrigation on needle morphology, shoot and stem growth in a drought-exposed Pinus sylvestris forest. Tree Physiol 30:346-360. doi:10.1093 /treephys/tpp 123

Feichtinger LM, Eilmann B, Buchmann N, Rigling A (2015) Traitspecific response of scots pine to irrigation on a short vs long time scale. Tree Physiol 35:160-171. doi:10.1093/treephys/tpul 14

Foster AS, Gifford EM Jr (1974) Comparative morphology of vascular plants, $2 d$ edn. Freeman, San Francisco

Garrett PW, Zahner R (1973) Fascicle density and needle growth responses of red pine to water supply over two seasons. Ecology 54 : $1328-1334$

Goss RJ (1966) Hypertrophy versus hyperplasia. Science 153:1615-1620

Haber AH, Long TJ, Foard DE (1964) Is final size determined by rate and duration of growth? Nature 201:479-480

Hay RKM, Kemp DR (1990) Primordium initiation at the stem apex as the primary event controlling plant development: preliminary evidence from wheat for the regulation of leaf development. Plant Cell Env 13:1005-1008

Huang J-G, Deslauriers A, Rossi S (2014) Xylem formation can be modeled statistically as a function of primary growth and cambium activity. New Phytol 203:831-841. doi:10.1111/nph. 12859

Kramer PJ, Kozlowski TT (1979) Physiology of woody plants. Academic Press, Baltimore

Kremer A, Larson PR (1983) Genetic control of height growth components in jack pine seedlings. For Sci 299:451-464

Lanner RM (1964) Temperature and the diurnal rhythm of height growth in pines. J For 62:493-495

Lanner RM (1966) Phenology and growth habits of pines in Hawaii. U. S. Forest Service Res. Pap. PSW-29. Berkeley

Lanner RM (1968) The pine shoot primary growth system. Dissertation, University of Minnesota

Lanner RM (1976) Patterns of shoot development in Pinus and their relationship to growth potential. In: Cannell MGR, Last FT (eds) Tree physiology and yield improvement. Academic, London, pp 223-243

Lanner RM (1978) Development of the terminal bud and shoot of slash pine saplings. For Sci 24:167-179

Lanner RM (1989) An observation on apical dominance and the umbrella-crown of Italian stone pine (Pinus pinea, Pinaceae). Econ Bot 43:128-130

Lanner RM, Connor KF (1988) Control of shoot elongation in ponderosa pine: relative roles of apical and axillary meristems. Tree Physiol 4: 233-243

Larson PR (1964) Some indirect effects of environment on wood formation. In: Zimmermann MH (ed) The formation of wood in forest trees. Academic, London, pp 345-365

Li X (2016) The onset of xylogenesis is not related to distance from the crown in smith fir trees from the southeastern Tibetan plateau. Can J For Res 46:885-889. doi:10.1139/cjfr-2016-0092
Little CHA (1970) Apical dominance in long shoots of white pine. Can J Bot 48:239-253

Little CHA, MacDonald JE (2003) Effects of exogenous gibberellin and auxin on shoot elongation and vegetative bud development in seedlings of Pinus sylvestris and Picea glauca. Tree Physiol 23:73-83

Lupi C, Rossi S, Vieira J, Morin H, Deslauriers A (2014) Assessment of xylem phenology: a first attempt to verify its accuracy and precision. Tree Physiol 34:87-93. doi:10.1093/treephys/tpt108

MacDonald JE, Little CH (2006) Foliar application of GA3 during terminal long-shoot bud development stimulates shoot apical meristem activity in Pinus sylvestris seedlings. Tree Physiol 26:1271-1276

Major JE, Mosseler A, Barsi DC, Clouthier A, Campbell M (2009) Impact of three silvicultural treatments on weevil incidence, growth, phenology, and branch-level dynamics of Pinus strobus from large and small populations. Can J For Res 39:12-25. doi:10.1139/X08153

Myers DA, Thomas RB, DeLucia EH (1999) Photosynthetic responses of loblolly pine (Pinus taeda) needles to experimental reduction in sink demand. Tree Physiol 19:235-242

Norgren O, Little CHA, Sundblad L-G (1996) Seedling shoot, needle and bud development in three provenances of Pinus sylvestris and Pinus contorta cultivated in northern Sweden. Scand J For Res 11:356363

Paul MJ, Foyer CH (2001) Sink regulation of photosynthesis. J Exp Bot 52:1383-1400. doi:10.1093/jexbot $/ 53.360 .1383$

Powell GR (2009) Lives of conifers. Johns Hopkins, Baltimore

Quentin AG, Close DC, Hennen LMHP, Pinkard EA (2014) Downregulation of photosynthesis via sink limitation is linked to foliar soluble sugar content in high- and low-yielding varieties of sweet cherry. Acta Hort 1058:351-356

Ribeiro RV, Machado EC, Habermann G, Santos MG, Oliveira RF (2012) Seasonal effects on the relationship between photosynthesis and leaf carbohydrates in orange trees. Func Plant Biol 39:471-480. doi:10.1071/FP11277

Rossi S, Rathgeber CBK, Deslauriers A (2009) Comparing needle and shoot phenology with xylem development on three conifer species in Italy. Ann For Sci 66:206. doi:10.1051/forest/2008088

Rossi S, Anfodillo T, Cufar K, Cuny HE, Deslauriers A, Fonti P, Frank D, Gricar J, Gruber A, King GM, Krause C, Morin H, Oberhuber W, Prislan P, Rathgeber CBK (2013) A meta-analysis of cambium phenology and growth: linear and non-linear patterns in conifers of the northern hemisphere. Ann Bot 112:1911-1920. doi:10.1093 /aob/met243

Ryan MG, Asao S (2014) Phloem transport in trees. Tree Physiol 34:1-4. doi:10.1093/treephys/tpt 123

Salminen H, Jalkanen R (2004) Does current summer temperature contribute to the final shoot length on Pinus sylvestris? A case study at the northern conifer timberline. Dendrochron 21:79-84. doi:10.1078/1125-7865-00039

Salminen H, Jalkanen R (2007) Intra-annual height increment of Pinus sylvestris at high latitudes in Finland. Tree Physiol 27:1347-1353

Sarvas R (1974) Investigations on the annual cycle of development of forest trees. II. Autumn dormancy and winter dormancy. Comm. Inst. For. Fenn. 84.1, Helsinki

Schiestl-Aalto P, Nikinmaa E, Mäkelä A (2013) Duration of shoot elongation in scots pine varies within the crown and between years. Ann Bot 112:1181-1191. doi:10.1093/aob/mct180

Sinnott EW (1960) Plant morphogenesis. McGraw-Hill, New York

Sundberg B, Uggla C (1998) Origin and dynamics of indoleacetic acid under polar transport in Pinus sylvestris. Physiol Plant 104:22-29

Tepper H (1969) Réactivation mitotique du bourgeon terminal et de cambium chez le Pinus resinosa. L C R Acad Sci Paris Sér D 268:80-82

Tschaplinski TJ, Blake TJ (1995) Growth and carbohydrate status of coppice shoots of hybrid poplar following shoot pruning. Tree Physiol 15:333-338 
Uggla C, Moritz T, Sandberg G, Sundberg B (1996) Auxin as a positional signal in pattern formation in plants. Proc Natl Acad Sci U S A 93: 9282-9286

Wang Q, Little CHA, Odén PC (1997) Control of longitudinal and cambial growth by gibberellins and indole-3-acetic acid in current-year shoots of Pinus sylvestris. Tree Physiol 17:715-721
Wardlaw CW (1968) Morphogenesis in plants, a contemporary study. Methuen, London

Worrall J, Draper DA, Andersen SA (1985) Periphysis in stagnant lodgepole pine; an hypothesis demolished. In: Tigerstedt PMA, Puttonen P, Koski V (eds) Crop physiology of forest trees. Helsinki University Press, Helsinki, pp 65-70 